\title{
PENGARUH KEPUASAN KERJA TERHADAP PEMBERDAYAAN MELALUI PENGALAMAN KERJA PERUSAHAAN TELEKOMUNIKASI
}

\author{
Erik Wardhana *) \\ *) Dosen Tetap Prodi Manajemen Fakultas Ekonomi \\ Universitas Krisnadwipayana Jakarta \\ Email : wardhana.pertama@gmail.com
}

\begin{abstract}
The background of this research examines the effects of job satisfaction and work experience on employee-desire for empowerment. The objectives of this research was analyzed the effect of job satisfaction on empowerment, the effect of job satisfaction on work experience, the effect of work experience on empowerment. A sampling with purposive sampling techniques of two hundred Employee's in Telecommunication company as the respondents provided the data that were analyzed for this study. Using a sub-set of the sample consisting of was used to test three hypothesized relationships in the model. Data analysis in this research was used Structural Equation Model (SEM) to test the independent variables influence the dependent variable. The findings help to explain failures in organizational efforts to empower workers by demonstrating the critical role of job satisfaction and work experience behaviors in heightening employee-desire for empowerment.
\end{abstract}

Keywords: Kepuasan kerja terhadap pemberdayaan melalui pengalaman kerja

\section{PENDAHULUAN}

Pemberdayaan karyawan bermakna lebih luas dibandingkan istilah partisipasi karyawan. Dalam pemberdayaan terdapat pendelegasian wewenang yang diberikan kepada karyawan tertentu dalam pengambilan keputusan sejauh tidak menyimpang dari kebijakan organisasi. Pemberdayaan yang ditujukan kepada karyawan dapat membuat perusahaan menjadi lebih fleksibel dan tanggap terhadap kondisi di dalam perusahaan. Pemberdayaan karyawan dilakukan dengan saling bertukar pengetahuan dan informasi sehingga kemampuan bekerja dari dalam diri karyawan dapat meningkat. Pemberdayaan dapat meningkatkan keterlibatan dan partisipasi dari dalam diri karyawan sehingga karyawan dapat mencapai tujuan dalam jangka panjang yang telah ditetapkan oleh perusahaan. Pemberdayaan karyawan sebagai bentuk pemberian wewenang dan tanggung jawab dari pimpinan kepada bawahan sehingga karyawan lebih cepat untuk mengambil keputusan (Arneson dan Ekberg, 2006). Pemberdayaan karyawan difokuskan ke karyawan, tingkat terbawah dalam setiap organisasi. Pemberdayaan karyawan adalah pemberian wewenang kepada karyawan untuk merencanakan, mengendalikan, dan membuat keputusan tentang pekerjaan yang menjadi tanggung jawabnya, tanpa harus mendapatkan otorisasi secara eksplisit dari manajer di atasnya. Jika di dalam pendelegasian wewenang, kekuasaan diberikan oleh manajemen puncak kepada para manajer di bawahnya (bukan kepada karyawan), dalam pemberdayaan karyawan, kekuasaan digali dari dalam diri setiap karyawan melalui proses pemberdayaan karyawan (employee empowerment). Pemberian wewenang oleh manajemen kepada karyawan dilandasi oleh peningkatan kemampuan yang dimiliki oleh karyawan dihasilkan dari proses pemberdayaan yang dilaksanakan oleh manajemen terhadap karyawan. Pemberdayaan karyawan dapat membuat 
karyawan bekerja lebih fleksibel, karyawan diberikan kebebasan untuk mengambil keputusan yang berhubungan dengan pekerjaan (Greasley, et al, 2008).

Oleh karena itu, pemberdayaan karyawan dilaksanakan dengan menggali potensi yang terdapat di dalam diri karyawan, maka pemberdayaan berarti pengembangan kekuasaan, bukan sekadar pendistribusian kekuasaan yang telah ada dan yang telah dimiliki oleh manajemen.. Misalnya ketika pimpinan berhalangan mengkoordinasi rapat tim kerja di unitnya maka dia bisa mendelegasikan kepada seseorang yang dianggap pantas (memiliki kemampuan manajerial dan kepemimpinan) untuk memimpin sebuah rapat. Atau bisa berupa pendelegasian pada ketua tim kerja subunit tetentu untuk menyusun dan mengatur kegiatan dan jadwal kerja.. Oleh karena itu, konsep pemberdayaan dimulai dari keyakinan bahwa orang pada dasarnya ingin mengerjakan pekerjaan baik, manajer tidak perlu lagi menerapkan metode guna membujuk karyawan untuk mengerahkan usaha mereka. Manajer harus memastikan bahwa karyawan memiliki pengetahuan dan teknologi yang diperlukan untuk pekerjaan mereka, dan manajer harus mendukung usaha karyawan dengan menghilangkan hambatan apa pun yang mencegah terwujudnya kinerja unggul. Dengan adanya pemberdayaan yang diberikan kepada karyawan maka kemampuan bekerja dari dalam diri karyawan dapat meningkat (Sarwar dan Khalid, 2011).

Pemberdayaan karyawan pun ditentukan oleh pengalaman kerja yang dimiliki oleh karyawan (Gill, et al, 2012). Pengalaman kerja yang dimiliki oleh karyawan merupakan salah satu cara di dalam proses pembentukan pengetahuan atau keterampilan tentang metode suatu pekerjaan karena keterlibatan karyawan tersebut dalam pelaksanaan tugas pekerjaan. Pengalaman kerja dapat meningkatkan pengetahuan atau keterampilan yang telah diketahui dan dikuasai seseorang yang akibat dari perbuatan atau pekerjaan yang telah dilakukan selama beberapa waktu tertentu karyawan yang berpengalaman akan memiliki gerakan yang mantap dan lancar, gerakannya berirama, lebih cepat menanggapi tanda-tanda, dapat menduga akan timbulnya kesulitan sehingga lebih siap menghadapinya, dan bekerja dengan tenang serta dipengaruhi faktor lain yaitu: lama waktu atau masa kerja seseorang, tingkat pengetahuan atau keterampilan yang telah dimiliki dan tingkat penguasaan terjadap pekerjaan dan peralatan. Oleh karena itu seorang karyawan yang mempunyai pengalaman kerja adalah seseorang yang mempunyai kemampuan jasmani, memiliki pengetahuan, dan keterampilan untuk bekerja serta tidak akan membahayakan bagi dirinya dalam bekerja. Dengan adanya pengalaman kerja yang dimiliki oleh seorang karyawan dapat meningkatkan keahlian bekerja dari dalam diri karyawan tersebut (Sallop dan Kirby, 2007).

Pengalaman yang dimiliki oleh karyawan dapat meningkat karena adanya perasaan positif dari dalam diri karyawan terhadap pekerjaan yang dimilikinya (Gill, et al, 2012). Kepuasan kerja merupakan perasaan seseorang terhadap pekerjaan. Kepuasan kerja merupakan masalah yang sering terjadi di dalam perusahaan karena kepuasan kerja menunjukkan perasaan suka atau tidak suka terhadap pekerjaan yang dimilikinya. Kepuasan kerja sangat berhubungan dengan kualitas hidup karyawan. Kepuasan kerja yang dimiliki oleh karyawan harus diciptakan sebaikbaiknya supaya moral kerja, dedikasi, kecintaan, dan kedisiplinan karyawan meningkat. Sikap ini dicerminkan oleh moral kerja, kedisiplinan, dan prestasi kerja. Kepuasan kerja dinikmati dalam pekerjaan, luar pekerjaan, dan kombinasi 
dalam dan luar pekerjaan. Adapun perasaan positif tentang pekerjaan sebagai hasil evaluasi karakterkarakter pekerjaan tersebut (Robbins dan Judge, 2009).

Kepuasan kerja menentukan sikap dan perilaku yang dimiliki oleh karyawan ketika menghadapi pekerjaan. Seorang pimpinan pun harus dapat memahami emosional yang dimiliki oleh karyawan ketika menghadapi pekerjaan. Kepuasan kerja adalah cara pegawai merasakan dirinya atau pekerjaannya. Perasaan yang berhubungan dengan pekerjaan melibatkan aspek-aspek seperti upaya, kesempatan pengembangan karir, hubungan dengan pegawai lain, penempatan kerja, dan struktur organisasi. Sementara itu, perasaan yang berhubungan dengan dirinya antara lain berupa umur, kondisi kesehatan, kemampuan dan pendidikan. Adapun, faktor-faktor lainnya yang menentukan kepuasan kerja dari dalam diri karyawan seperti pekerjaan itu sendiri, atasan, teman satu pekerjaan, promosi, dan gaji. Kepuasan kerja sebagai respon sikap atau emosi terhadap berbagai segi pekerjaan seseorang (Kinicki dan Kreitner, 2005).

Penelitian ini memiliki tujuan untuk menganalisis pengaruh kepuasan kerja terhadap pemberdayaan melalui pengalaman kerja.

\section{LANDASAN TEORI}

\section{Kepuasan Kerja}

Menurut Robbin (2008), pengertian kepuasan kerja (Job Satisfaction) adalah perasaan positif tentang pekerjaan seseorang yang merupakan hasil dari evaluasi karakteristik-karakteristiknya. Seseorang yang memiliki kepuasan kerja yang tinggi memiliki perasaan-perasaan positif tentang pekerjaan tersebut, sementara seseorang yang tidak puas memiliki perasaan-perasaan yang negatif tentang pekerjaan tersebut. Seseorang yang memiliki kepuasan kerja yang tinggi memiliki perasaan-perasaan positif tentang pekerjaan tersebut, sementara seseorang yang tidak puas memiliki perasaan-perasaan yang negatif tentang pekerjaan tersebut. Bhal dan Gulati (2006) menyatakan definisi kepuasan kerja adalah suatu penilaian perasaan positif yang dimiliki oleh karyawan terhadap pekerjaan secara keseluruhan. Gunlu (2010) menyatakan definisi kepuasan kerja adalah suatu perasaan atau perilaku karyawan berhubungan dengan pekerjaan dan komponen pekerjaan seperti lingkungan pekerjaan, kondisi pekerjaan, imbalan dan komunikasi antar karyawan. Rose (2009) menyatakan bahwa karyawan yang memiliki tingkat kepuasan kerja tinggi maka karyawan tersebut merasa puas terhadap pekerjaannya sehingga karyawan dapat bekerja sama, membantu, dan saling menghargai, dan melakukan pekerjaan dengan baik dan maksimal.

Zimmerman dan Darnold (2009) menyatakan bahwa dengan adanya kepuasan kerja dapat meningkatkan prestasi kerja karyawan sesuai dengan pernyataan expectancy theory bahwa dengan adanya prestasi kerja yang tinggi diperoleh dengan adanya kepuasan kerja karyawan. Kepuasan kerja penting dalam menciptakan efektivitas perusahaan (Lim, 2008). Gonzalez dan Garazo (2006) mengungkapkan bahwa para manajer harus meningkatkan kepuasan kerja karyawan sehingga akan meningkatkan layanan jasa. Abdulla, Djebarni dan Mellahi (2011) menyatakan bahwa kepuasan kerja yang dimiliki oleh karyawan dapat meningkatkan produktivitas perusahaan, menurunkan kemangkiran yang dilakukan oleh karyawan, dan meningkatkan efektivitas yang dicapai oleh perusahaan. Maka dapat disimpulkan bahwa tujuan kepuasan kerja adalah kepuasan kerja dapat meningkatkan prestasi kerja karyawan dan efektivitas perusahaan. 
Fichter (2010) menyatakan dimensi dari pembentukan kepuasan kerja karyawan adalah: 1). The work itself (pekerjaan itu sendiri); Pekerjaan merupakan faktor yang menyebabkan timbulnya kepuasan kerja yang terdiri dari kreativitas, bermacam-macam tugas, adanya peningkatan pengetahuan karyawan dan perubahan dalam tanggung jawab, jumlah pekerjaan, perluasan pekerjaan, dan kompleksitas pekerjaan. 2). Salary (gaji yang diterima karyawan); Gaji merupakan faktor yang menyebabkan kepuasan kerja karyawan dengan membandingkan antara gaji yang diterima secara aktual dari karyawan dengan gaji yang diharapkan oleh karyawan tersebut. 3). Opportunity for promotion (kesempatan adanya promosi jabatan dalam pekerjaan); Promosi merupakan faktor yang menyebabkan kepuasan kerja karyawan yaitu kebijakan perusahaan yang berhubungan dengan promosi organisasi dan administrasi. 4). Supervision and coworkers (pimpinan dan bawahan); Pimpinan merupakan faktor yang menyebabkan timbulnya kepuasan kerja karyawan berhubungan dengan pimpinan dalam organisasi tempat karyawan bekerja. Bawahan yang berada dalam organisasi tempat karyawan tersebut bekerja juga merupakan faktor yang menyebabkan terbentuknya kepuasan kerja karyawan.

\section{Pengalaman Kerja}

Pengertian pengalaman kerja (work experience) adalah sebagai suatu ukuran tentang lama waktu atau masa kerjanya yang telah ditempuh seseorang dalam memahami tugas-tugas suatu pekerjaan dan telah melaksanakannya dengan baik (Foster, 2001). Scroggins (2008) mendefinisikan Work Experience adalah suatu nilai yang diperoleh oleh karyawan ketika bekerja di dalam perusahaan. Gill, et al (2012) mendefinisikan Work Experience adalah suatu pengalaman yang diperoleh oleh karyawan selama bekerja di dalam perusahaan. Ali, Shaharudin, dan Anuar (2012) memberikan pengertian Work Experience adalah lamanya karyawan bekerja pada perusahaan.

Poon (2004) menjelaskan bahwa pengalaman kerja yang dimiliki oleh karyawan dapat menciptakan keberhasilan karir yang dimiliki oleh karyawan. Sulis (2009) menjelaskan bahwa karyawan yang memiliki pengalaman kerja yang lebih lama maka karyawan tersebut memiliki gaji yang lebih tinggi. Cunnien, et al (2009) menemukan bahwa tujuan dari peningkatan pengalaman kerja yang dimiliki oleh karyawan adalah meningkatnya kemampuan bekerja dari dalam diri karyawan. Rooy, et al (2005) menemukan bahwa karyawan yang memiliki pengalaman kerja lebih lama maka karyawan akan lebih memiliki kecerdasan emosional.

\section{Pemberdayaan}

Humborstad dan Perry (2011) memberikan pengertian pemberdayaan karyawan (employee empowerment) adalah suatu insiatif yang timbul dari dalam diri karyawan untuk mengambil keputusan tanpa bertanya kepada pimpinan sehingga menciptakan keterlibatan karyawan dan partisipasi aktif dari dalam diri karyawan. Sunaryo (2009) bahwa pemberdayaan karyawan adalah pemberian kesempatan dan dorongan kepada para karyawan untuk mendayagunakan bakat, ketrampilanketrampilan, sumberdaya-sumberdaya, dan pengalaman-pengalaman mereka untuk menyelesaikan pekerjaan secara tepat waktu. Mbaidin dan Yousef (2010) mendefinisikan pemberdayaan karyawan adalah suatu partisipasi dan keterlibatan karyawan di dalam menghadapi pekerjaan. Neghabi dan Rafiee (2012) mendefinisikan pemberdayaan karyawan adalah suatu pemberian wewenang dari pimpinan perusahaan kepada karyawan 
untuk mengambil keputusan. Shekari, et al, (2011) memberikan pengertian pemberdayaan karyawan adalah suatu pemberian wewenang kepada karyawan untuk menjalankan fungsi di dalam perusahaan. Dewettinck dan Ameijde (2011) berpendapat mengenai pengertian pemberdayaan karyawan adalah suatu pendelegasian terhadap pengambilan keputusan dan tanggung jawab dari seorang pimpinan kepada karyawan sebagai bawahan.

Albrecht dan Andreetta (2011) mendefinisikan pemberdayaan karyawan adalah suatu pemberian wewenang dari seorang pimpinan perusahaan kepada karyawan untuk mengendalikan, memberikan kekuasaan, memberikan otonomi, menciptakan partisipasi, dan mengambil keputusan berhubungan dengan pekerjaan. Robbins dan Judge (2008) mendefinisikan pemberdayaan karyawan adalah suatu proses pendelegasian di dalam pengambilan keputusan dari pimpinan kepada bawahan. Menurut Baird dan Wang (2010), pemberdayaan karyawan adalah suatu pendelegasian wewenang dan tanggung jawab dari karyawan yang memiliki struktur organisasi yang lebih tinggi ke karyawan yang memiliki struktur organisasi yang lebih rendah untuk mengambil keputusan.

Dost dan Shaheen

menemukan bahwa tujuan pembentukan pemberdayaan karyawan adalah untuk meningkatkan produktivitas perusahaan. Humborstad dan Perry (2011) menjelaskan tujuan pembentukan pemberdayaan karyawan adalah untuk membentuk insiatif dan keterlibatan karyawan di dalam pengambilan keputusan. Abraiz, et al, (2012) menjelaskan bahwa bahwa tujuan pembentukan pemberdayaan karyawan adalah untuk membentuk kepuasan kerja dari dalam diri karyawan. Rivai dan Sagala (2009) menemukan tujuan pembentukan pemberdayaan karyawan adalah untuk mencapai tujuan yang telah ditetapkan oleh perusahaan. Baird dan Wang (2010) juga menyatakan bahwa tujuan pimpinan perusahaan menciptakan pemberdayaan bagi karyawan untuk mencapai keberhasilan perusahaan. Boudrias, et al, (2009) menemukan tujuan dari dilakukan pemberdayaan karyawan adalah untuk meningkatkan produktivitas karyawan dengan cara memberikan wewenang dan tanggung jawab kepada karyawan. Swidi, et al, (2012) menyatakan tujuan dari pembentukan pemberdayaan karyawan adalah untuk menciptakan komitmen organisasi. Judith (2012) menemukan adanya tujuan pembentukan pemberdayaan karyawan adalah untuk menciptakan keterlibatan dan komitmen karyawan yang bekerja di dalam perusahaan. Raquib, et al, (2010) menemukan tujuan dari pembentukan pemberdayaan karyawan adalah untuk memberikan wewenang dan kekuasaan kepada karyawan dan untuk meningkatkan keahlian yang dimiliki oleh karyawan.

\section{METODE PENELITIAN}

\section{Rancangan Penelitian}

Penelitian ini sesuai dengan penelitian yang dilakukan oleh Gill, et al, (2012. menganalisis pengaruh kepuasan kerja terhadap pemberdayaan melalui pengalaman kerja. Rancangan penelitian yang digunakan dalam penelitian ini menggunakan pengujian hipotesis (hypotheses testing) adalah penelitian yang bertujuan untuk menguji hipotesis penelitian yang pada umumnya menjelaskan tentang karakteristik pengaruh-pengaruh tertentu atau perbedaan-perbedaan antar kelompok atau independensi dari dua faktor atau lebih dalam suatu situasi (Sekaran, 2006). 


\section{Metode Pengumpulan Data}

Jumlah sampel dalam penelitian ini dilakukan dengan cara menyebarkan kuesioner kepada 200 karyawan PT. Hamparan Rezeki Prima dari jumlah populasi yang ada sebanyak 350 karyawan. Teknik pengambilan sampel yang digunakan adalah purposive sampling. Dalam penelitian ini cara penentuan jumlah sampelnya menggunakan rumus Slovin dengan perhitungannya (Hermawan, 2006), diperoleh sampel sebanyak 200 karyawan PT. Hamparan Rezeki Prima).

\section{HASIL PENELITIAN DAN PEMBAHASAN}

\section{Hasil Penelitian}

\section{Uji Validitas}

Uji validitas digunakan untuk mengetahui apakah semua item pertanyaan penelitian yang digunakan untuk mengukur variabel penelitian adalah valid. Pengujian validitas dilakukan dengan mencari keterkaitan dari setiap indikator terhadap variabel yang diteliti dengan menggunakan rumus teknik Confirmatory Factor Analyses dengan bantuan software AMOS versi 7 (Sekaran, 2006). Keputusan yang diambil dengan cara membandingkan nilai KMO MSA dari setiap variabel pernyataan $(\alpha$ $=0,05$ ). Dasar pengambilan keputusan uji validitas adalah sebagai berikut : Jika KMO MSA > $(0,5)$ maka item pernyataan valid. Jika KMO MSA < $(0,05)$ maka item pernyataan tidak valid.

Tabel 1. Hasil Uji Validitas

\begin{tabular}{|c|c|c|c|}
\hline Variabel dan Pernyataan & $\begin{array}{c}P- \\
\text { Value }\end{array}$ & $\begin{array}{l}\text { KMO } \\
\text { MSA }\end{array}$ & Keputusan \\
\hline \multicolumn{4}{|l|}{ Kepuasan Kerja } \\
\hline $\begin{array}{lrr}\text { Karyawan } & \text { merasa } & \text { aman } \\
\text { terhadap } & \text { pekerjaan } & \text { yang } \\
\text { dimilikinya. } & & \\
& & \end{array}$ & 0,000 & 0,557 & Valid \\
\hline $\begin{array}{l}\text { Karyawan merasa puas } \\
\text { terhadap gaji dan upah yang } \\
\text { diterima. }\end{array}$ & 0,000 & 0,711 & Valid \\
\hline $\begin{array}{l}\text { Karyawan merasa senang } \\
\text { terhadap pimpinan perusahaan. }\end{array}$ & 0,000 & 0,808 & Valid \\
\hline $\begin{array}{lrr}\text { Karyawan } & \text { merasa } & \text { puas } \\
\text { terhadap kebijakan } & \text { yang } \\
\text { dimiliki oleh perusahaan. } & \end{array}$ & 0,000 & 0,816 & Valid \\
\hline $\begin{array}{l}\text { Karyawan merasa senang } \\
\text { diberikan kesempatan untuk } \\
\text { maju dalam berkarir di } \\
\text { perusahaan }\end{array}$ & 0,000 & 0,833 & Valid \\
\hline \multicolumn{4}{|l|}{ Pengalaman Kerja } \\
\hline $\begin{array}{l}\text { Saya tidak menemukan masalah } \\
\text { di dalam mengekspresikan } \\
\text { emosional ketika menghadapi } \\
\text { pekerjaan. }\end{array}$ & 0,000 & 0,839 & Valid \\
\hline $\begin{array}{l}\text { Saya sering merasa sulit untuk } \\
\text { melihat sesuatu dari sudut } \\
\text { pandang orang lain. }\end{array}$ & 0,000 & 0,882 & Valid \\
\hline
\end{tabular}


Secara keseluruhan, saya
merupakan orang yang sangat memiliki motivasi.

Saya biasanya merasa sulit $0,000 \quad 0,872 \quad$ Valid untuk mengatur emosi saya.

Saya biasanya tidak menemukan kehidupan yang menyenangkan.

Saya dapat mengatasi masalah orang lain secara efektif.

Saya cenderung untuk $0,000 \quad 0,816 \quad$ Valid mengubah pikiran saya.

Saya sering tidak tahu perasaan

$0,000 \quad 0,860$

Valid apa yang saya rasakan.

Saya merasa bahwa say memiliki kualitas kerja yang baik.

Saya sering merasa sulit untuk membela hak-hak saya.

Saya dapat mempengaruhi perasaan orang lain. Secara keseluruhan, saya
merasa tidak jelas pada banyak hal.

Karyawan lain yang merasa $0,000 \quad 0,844$

Valid

$0,000 \quad 0,879$

Valid

dekat dengan saya sering mengeluh bahwa saya tidak memperlakukan orang lain secara tepat.

Saya sering merasa sulit untuk menyesuaikan hidup saya sesuai dengan keadaan.

Secara keseluruhan, saya bisa mengatasi stres kerja yang dihadapi.

Saya sering merasa sulit untuk $0,000 \quad 0,849$

Valid

$0,000 \quad 0,858$

Valid menunjukkan kasih sayang kepada orang-orang dekat dengan saya.

Saya dapat mengetahui pengalaman dan perasaan karyawan lain.

Saya biasanya merasa sulit untuk menjaga diri termotivasi.

Saya biasanya dapat

$0,000 \quad 0,846 \quad$ Valid

$0,000 \quad 0,896 \quad$ Valid

$0,000 \quad 0,868 \quad$ Valid

$0,000-0,844$

Valid

menemukan cara untuk mengendalikan emosi saya ketika saya ingin.

Secara keseluruhan, saya

$0,000 \quad 0,870 \quad$ Valid

$0,000 \quad 0,858 \quad$ Valid

$0,000 \quad 0,880 \quad$ Valid

$0,000 \quad 0,850 \quad$ Valid

$0,000 \quad 0,860 \quad$ Valid

$0,000 \quad 0,847 \quad$ Valid

Secara keseluruhan, saya 
senang dengan hidup saya.

\begin{tabular}{lccc}
\hline Pemberdayaan & & & \\
\hline $\begin{array}{l}\text { Karyawan dapat mengambil } \\
\text { keputusan untuk mengatasi } \\
\text { masalah pekerjaan. }\end{array}$ & 0,000 & 0,968 & Valid \\
$\begin{array}{l}\text { Karyawan ingin mengatasi } \\
\text { masalah. }\end{array}$ & 0,000 & 0,965 & Valid \\
$\begin{array}{l}\text { Karyawan percaya terhadap } \\
\text { keputusan perusahaan. }\end{array}$ & 0,000 & 0,964 & Valid \\
$\begin{array}{l}\text { Karyawan merasa diberikan } \\
\text { kebebasan di dalam } \\
\text { menghadapi pekerjaan. }\end{array}$ & 0,000 & 0,753 & Valid \\
\hline
\end{tabular}

Hal ini menunjukkan bahwa variabel yang diteliti yaitu kepuasan kerja, pengalaman kerja, dan pemberdayaan diperoleh nilai KMO MSA lebih dari 0,5 (KMO MSA >,05) terlihat valid (dapat diukur).

\section{Uji Reliabilitas}

Suatu uji reliabilitas pada alat ukur perlu dilakukan untuk memastikan instrumen dari alat ukur yang digunakan untuk penelitian ini adalah konsisten dan akurat. Reliabilitas berkaitan dengan konsistensi, akurasi, dan prediktabilitas suatu alat ukur (Hermawan, 2006). Menurut Sekaran (2006), dasar pengambilan keputusan uji reliabilitas ini adalah sebagai berikut: a). Jika koefisien Cronbach's Alpha $\geq 0,6 \rightarrow$ maka Cronbach's Alpha acceptable (construct reliable). b). Jika koefisien Cronbach's Alpha $<0,6 \rightarrow$ maka Cronbach's Alpha poor acceptable (construct unreliable).

Tabel 2. Hasil Uji Reliabilitas

\begin{tabular}{lcc}
\hline \multicolumn{1}{c}{ Variabel } & Cronbach Alpha & Keputusan \\
\hline Kepuasan kerja & 0,960 & Reliable \\
Pengalaman kerja & 0,981 & Reliable \\
Pemberdayaan & 0,934 & Reliable \\
\hline
\end{tabular}

Hal ini menunjukkan bahwa variabel yang diteliti yaitu kepuasan kerja, pengalaman kerja, dan pemberdayaan diperoleh nilai signifikan (p-value) lebih dari 0,6 maka terlihat konsisten (Reliable).

\section{Metode Analisis Data}

Metode analisis data yang digunakan dengan uji goodness of fit model dilakukan sesuai dengan kriteria sebagai berikut : 1). $\chi^{2}-$ Chi-Square statistic, semakin kecil nilai $\chi^{2}$ semakin baik model itu, dan diterima berdasarkan probabilitas dengan cut-off value sebesar p> 0,05. 2). RMSEA (The Root Mean Square Error of Approximation), merupakan suatu indeks yang digunakan untuk mengkonpensasi chi-square dalam sampel yang besar. 3). GFI (Goodness of fit Index), merupakan ukuran non statistical yang mempunyai rentang nilai antara 0 sampai dengan 1 . Nilai yang tinggi dalam indeks ini menunjukkan sebuah "better fit". 4). AGFI (Adjusted Goodness of Fit Index), merupakan kriteria yang memperhitungkan proporsi tertimbang dari varian dalam sebuah matrik kovarian sampel. 5). CMIN/DF (The Minimum Sample Discrepancy Function Devided with degrre of Freedom), merupakan statistic chi square $\mathrm{X}^{2}$ dibagi degree of freedom-nya sehingga disebut $X^{2}$ relatif. 6). TLI 
(Tucker Lewis Indeex), merupakan incremental index yang membandingkan sebuah model yang diuji terhadap sebuah baseline model. 7). CFI (Comparative Fit Index), rentang nilai sebesar 0-1, dimana semakin mendekati 1, mengindikasikan tingkat fit yang paling tinggi. 8). NFI (Normed Fit Index), Nilai NFI mulai 0-1 diturunkan dari perbandingan antara model yang dihipotesiskan dengan suatu model independen tertentu. Model mempunyai kecocokan tinggi jika nilai mendekati 1. Hasil uji goodness of fit model ditunjukkan pada Tabel 3 sebagai berikut:

Tabel 3: Hasil Uji Goodness of Fit Model

\begin{tabular}{cccc}
\hline $\begin{array}{c}\text { Pengukuran } \\
\text { Goodness of Fit }\end{array}$ & $\begin{array}{c}\text { Batas Penerimaan } \\
\text { Yang Disarankan }\end{array}$ & Nilai & Keputusan \\
\hline$\chi^{2} / d f$ & $<5,00$ & 1,085 & Acceptable Fit \\
$p$-value & $>0,05$ & 0,125 & Acceptable Fit \\
GFI & $>0,80$ atau & 0,871 & Acceptable Fit \\
& mendekati 1 & & \\
RMSEA & $<0,08$ & 0,021 & Acceptable Fit \\
CFI & $>0,90$ & 0,995 & Acceptable Fit \\
NFI & $>0,80$ & 0,942 & Acceptable Fit \\
\hline
\end{tabular}

Sumber: Hair et al. (2006)

Dalam Tabel 3 tersebut terlihat hasil goodness of fit model bahwa model penelitian belum memenuhi syarat-syarat kesesuaian model. Untuk nilai ChiSquare telah menunjukkan sempurna (Pvalue $=0,125)$, selain itu nilai GFI juga telah fit dimana nilai GFI diperoleh sebesar 0,871, nilai RMSEA juga telah fit diperoleh sebesar 0,021, nilai CFI juga telah fit diperoleh sebesar 0,995 , dan nilai NFI juga telah fit diperoleh sebesar 0,942 .

\section{HASIL PENELITIAN DAN PEMBAHASAN}

Tabel 4: Uji Hipotesis

\begin{tabular}{ccccc}
\hline Hipotesis & & $\begin{array}{c}\text { Standardized } \\
\text { Coefficient } \\
\text { Beta }(\boldsymbol{\beta})\end{array}$ & p-value & Keputusan \\
\hline $\begin{array}{c}\mathrm{H}_{1}: \text { Kepuasan kerja } \\
\text { Pemberdayaan }\end{array}$ & 0,315 & 0,000 & $\begin{array}{c}\mathrm{Ho}_{1} \text { ditolak, } \\
\mathrm{Ha}_{2} \text { diterima }\end{array}$ \\
\begin{tabular}{c}
$\mathrm{H}_{2}: \begin{array}{l}\text { Kepuasan kerja } \\
\text { Pengalaman kerja } \\
\mathrm{H}_{3}: \text { Pengalaman kerja } \\
\text { Pemberdayaan }\end{array}$ \\
\hline
\end{tabular} & 0,213 & 0,001 & $\begin{array}{c}\mathrm{Ho}_{2} \text { ditolak, } \\
\mathrm{Ha}_{2} \text { diterima }\end{array}$ \\
\hline
\end{tabular}

Hipotesis 1:

Bunyi hipotesis null $\left(\mathrm{H}_{0}\right)$ dan hipotesis alternatif $\left(\mathrm{H}_{\mathrm{a}}\right)$ adalah sebagai berikut:

$\mathrm{H}_{01}$ : Kepuasan kerja tidak memiliki pengaruh positif terhadap pemberdayaan.
$\mathrm{H}_{\mathrm{a} 1}$ : Kepuasan kerja memiliki pengaruh positif terhadap pemberdayaan. Pada pengujian hipotesis 1 diketahui $p$-value $0,000<$ alpha 0,05 dengan nilai beta sebesar 0,315 maka $\mathrm{H}_{01}$ ditolak yang artinya kepuasan kerja memiliki pengaruh positif terhadap 
pemberdayaan. Dengan adanya peningkatan terhadap kepuasan kerja dari dalam diri karyawan maka karyawan pun lebih menginginkan untuk diberikan pemberdayaan. Hal ini ditunjukkan dengan adanya karyawan merasa puas terhadap kebijakan yang dimiliki oleh perusahaan sehingga karyawan dapat mengambil keputusan untuk mengatasi masalah pekerjaan.

\section{Hipotesis 2:}

Bunyi hipotesis null $\left(\mathrm{H}_{0}\right)$ dan hipotesis alternatif $\left(\mathrm{H}_{\mathrm{a}}\right)$ adalah sebagai berikut:

$\mathrm{H}_{02}$ : Kepuasan kerja tidak memiliki pengaruh positif terhadap pengalaman kerja.

$\mathrm{H}_{\mathrm{a} 2}$ : Kepuasan kerja memiliki pengaruh positif terhadap pengalaman kerja.

Pada pengujian hipotesis 2 diketahui p-value $0,001<$ alpha 0,05 dengan nilai beta sebesar 0,213 maka $\mathrm{H}_{02}$ ditolak yang artinya kepuasan kerja memiliki pengaruh positif terhadap pengalaman kerja. Dengan adanya penilaian positif dari dalam diri karyawan terhadap pekerjaan yang dimilikinya dapat menciptakan pengalaman kerja yang baik ketika bekerja di dalam perusahaan. Hal ini ditunjukkan dengan adanya karyawan merasa puas terhadap kebijakan yang dimiliki oleh perusahaan sehingga saya dapat mengatasi masalah orang lain secara efektif.

\section{Hipotesis 3:}

Bunyi hipotesis null $\left(\mathrm{H}_{0}\right)$ dan hipotesis alternatif $\left(\mathrm{H}_{\mathrm{a}}\right)$ adalah sebagai berikut:

$\mathrm{H}_{03}$ : Pengalaman kerja tidak memiliki pengaruh positif terhadap pemberdayaan.

$\mathrm{H}_{\mathrm{a} 3}$ : Pengalaman kerja memiliki pengaruh positif terhadap pemberdayaan.

Pada pengujian hipotesis 3 diketahui $p$-value $0,004<$ alpha 0,05 dengan nilai beta sebesar 0,260 maka $\mathrm{H}_{03}$ ditolak yang artinya pengalaman kerja memiliki pengaruh positif terhadap pemberdayaan. Dengan adanya pengalaman kerja yang baik dari dalam diri karyawan ketika bekerja di dalam perusahaan dapat menciptakan keinginan diberikan pemberdayaan bagi karyawan. Hal ini ditunjukkan dengan adanya karyawan mampu bekerja dengan baik sehingga karyawan dapat mengambil keputusan untuk mengatasi masalah pekerjaan.

\section{Pembahasan}

Pada Tabel 4 terlihat pada hasil yang menguji tiga hipotesis penelitian bahwa kepuasan kerja memiliki pengaruh positif terhadap pemberdayaan, kepuasan kerja memiliki pengaruh positif terhadap pengalaman kerja, dan pengalaman kerja memiliki pengaruh positif terhadap pemberdayaan. Adapun pembahasan dari masing-masing hipotesis penelitian sebagai berikut:

\section{Hipotesis Satu: Kepuasan kerja memiliki pengaruh positif terhadap pemberdayaan.}

Kepuasan kerja timbul karena adanya keadaan emosional yang menyenangkan dengan mana para karyawan memandang pekerjaan mereka. Kepuasan kerja mencerminkan perasaan seseorang terhadap pekerjaannya. Ini dampak dalam sikap positif karyawan terhadap pekerjaan dan segala sesuatu yang dihadapi di lingkungan kerjanya. sikap emosional yang menyenangkan dan mencintai pekerjaannya. Kepuasan kerja dari dalam diri karyawan harus diciptakan sebaik-baiknya supaya moral kerja, dedikasi, kecintaan, dan kedisiplinan karyawan meningkat. Sikap ini dicerminkan oleh moral kerja, kedisiplinan, dan prestasi kerja. Kepuasan kerja dinikmati dalam pekerjaan, luar pekerjaan, dan kombinasi dalam dan luar pekerjaan. Kepuasan kerja dalam pekerjaan adalah kepuasan kerja 
yang dinikmati dalam pekerjaan dengan memperoleh pujian hasil kerja, penempatan, perlakuan, peralatan, dan suasana lingkungan kerja yang baik. Karyawan yang lebih suka menikmati kepuasan kerja dalam pekerjaan akan lebih mengutamakan pekerjaannya daripada balas jasa walaupun balas jasa itu penting. Dengan kepuasan kerja maka dapat menciptakan keinginan untuk memiliki keahlian dalam bekerja sehingga karyawan memiliki prestasi kerja yang lebih baik dan karyawan dapat mencapai tujuan yang telah ditetapkan oleh perusahaan. Pemberdayaan karyawan bermakna lebih luas ketimbang istilah partisipasi karyawan. Dalam pemberdayaan terdapat pendelegasian wewenang yang diberikan kepada karyawan tertentu dalam pengambilan keputusan sejauh tidak menyimpang dari kebijakan organisasi. Misalnya ketika pimpinan berhalangan mengkoordinasi rapat tim kerja di unitnya maka dia bisa mendelegasikan kepada seseorang yang dianggap pantas (kemampuan manajerial dan kepemimpinan) untuk memimpin rapat. Pemberdayaan karyawan berupa pendelegasian pada karyawan untuk menyusun dan mengatur kegiatan dan jadwal kerja. Jadi tampak pemberdayaan karyawan berimplikasi pada kebebasan dan kemampuan karyawan tertentu untuk membuat keputusan dan komitmen; tidak sekedar hanya berbagi informasi dan saran-saran. Pemberdayaan menyangkut tentang kewenangan dan penguatan otoritas dari karyawan tertentu.

Pada pengujian hipotesis 1 diketahui $p$ value $0,000<$ alpha 0,05 dengan nilai beta sebesar 0,315 maka $\mathrm{H}_{01}$ ditolak yang artinya kepuasan kerja memiliki pengaruh positif terhadap pemberdayaan. Dengan adanya pengaruh positif kepuasan kerja terhadap pemberdayaan menunjukkan bahwa dengan adanya penilaian positif dari dalam diri karyawan maka dapat menciptakan keinginan karyawan untuk diberdayakan agar karyawan lebih memiliki keahlian dalam bekerja. Hasil penelitian ini mendukung hasil penelitian yang dilakukan oleh Gill, Sharma, Mathur, dan Bhutani (2012). Di dalam penelitian Gill, Sharma, Mathur, dan Bhutani (2012) ditunjukkan bahwa besarnya pengaruh positif kepuasan kerja terhadap pemberdayaan diperoleh nilai beta sebesar 0,532 dan nilai signifikan kurang dari $0,000 \quad(\beta=0,532 ; p$ value $<0,005)$.

\section{Hipotesis Dua: Kepuasan kerja memiliki pengaruh positif terhadap pengalaman kerja.}

Kepuasan kerja adalah suatu keadaan emosi yang positif atau dapat menyenangkan yang dihasilkan dari suatu penilaian terhadap pekerjaan atau pengalaman-pengalaman kerja seseorang. Kepuasan kerja juga dapat diartikan sebagai perasaan dan penilaian seorang atas pekerjaannya, khususnya mengenai kondisi kerjanya, dalam hubungannya dengan apakah pekerjaannya mampu memenuhi harapan, kebutuhan, dan keinginannya. Karyawan yang memiliki pengalaman kerja di suatu perusahaan merupakan nilai tambah tersendiri apabila karyawan bekerja pada perusahaan yang memiliki reputasi dan kredibilitas yang baik.

Pada pengujian hipotesis 2 diketahui $p$-value $0,001<$ alpha 0,05 dengan nilai beta sebesar 0,213 maka $\mathrm{H}_{02}$ ditolak yang artinya kepuasan kerja memiliki pengaruh positif terhadap pengalaman kerja. Dengan adanya pengaruh positif kepuasan kerja terhadap pengalaman kerja menunjukkan bahwa dengan adanya perasaan positif dari dalam diri karyawan terhadap pekerjaan dapat menciptakan pengalaman baik dari dalam diri karyawan ketika bekerja di dalam perusahaan. Hasil penelitian ini mendukung hasil penelitian yang dilakukan oleh Gill, Sharma, Mathur, dan Bhutani (2012). Di dalam penelitian Gill, Sharma, Mathur, dan Bhutani (2012) 
ditunjukkan bahwa besarnya pengaruh positif kepuasan kerja terhadap pengalaman kerja diperoleh nilai beta sebesar 0,138 dan nilai signifikan kurang dari $0,005(\beta=0,138 ; p$-value $<0,005)$.

\section{Hipotesis Tiga: Pengalaman kerja memiliki pengaruh positif terhadap pemberdayaan.}

Pengalaman kerja menunjukkan tingkat penguasaan pengetahuan serta keterampilan seseorang dalam pekerjaannya yang dapat diukur dari masa kerja dan dari tingkat pengetahuan serta keterampilan yang dimilikinya. Pengukuran pengalaman kerja sebagai sarana untuk menganalisa dan mendorong efisiensi dalam pelaksanaan tugas pekerjaan. Seorang karyawan yang berpengalaman akan memiliki gerakan yang mantap dan lancar, gerakannya berirama, lebih cepat menanggapi tandatanda, dapat menduga akan timbulnya kesulitan sehingga lebih siap menghadapinya, dan bekerja dengan tenang serta dipengaruhi faktor lain yaitu lama waktu/masa kerja seseorang, tingkat pengetahuan atau keterampilan yang telah dimiliki dan tingkat penguasaan terhadap pekerjaan dan peralatan. Oleh karena itu seorang karyawan yang mempunyai pengalaman kerja adalah seseorang yang mempunyai kemampuan jasmani, memiliki pengetahuan, dan keterampilan untuk bekerja serta tidak akan membahayakan bagi dirinya dalam bekerja. Pengalaman kerja merupakan proses pembentukan pengetahuan atau keterampilan tentang metode suatu pekerjaan karena keterlibatan karyawan tersebut dalam pelaksanaan tugas pekerjaan. Pengalaman kerja adalah ukuran tentang lama waktu atau masa kerja yang telah ditempuh seseorang dapat memahami tugas-tugas suatu pekerjaan dan telah melaksanakan dengan baik. Pengalaman kerja sebagai bentuk pengetahuan atau keterampilan yang telah diketahui dan dikuasai seseorang yang akibat dari perbuatan atau pekerjaan yang telah dilakukan selama beberapa waktu tertentu.

Pada pengujian hipotesis 3 diketahui $p$-value $0,004<$ alpha 0,05 dengan nilai beta sebesar 0,260 maka $\mathrm{H}_{03}$ ditolak yang artinya pengalaman kerja memiliki pengaruh positif terhadap pemberdayan, artinya dengan adanya pengalaman kerja yang baik dari dalam diri karyawan ketika bekerja di dalam perusahaan dapat menciptakan keinginan diberikan pemberdayaan bagi karyawan. Hal ini ditunjukkan dengan adanya karyawan mampu bekerja dengan baik sehingga karyawan dapat mengambil keputusan untuk mengatasi masalah pekerjaan. Hasil penelitian ini mendukung hasil penelitian yang dilakukan oleh Gill, Sharma, Mathur, dan Bhutani (2012). Di dalam penelitian Gill, Sharma, Mathur, dan Bhutani (2012)ditunjukkan bahwa besarnya pengaruh positif pengalaman kerja terhadap pemberdayaan diperoleh nilai beta sebesar 0,176 dan nilai signifikan kurang dari $0,005 \quad(\beta=0,176$; $p$ value $<0,005)$.

\section{KESIMPULAN DAN SARAN}

\section{Kesimpulan}

Berdasarkan uraian dan analisis yang telah dikemukakan pada bab sebelumnya, maka simpulan yang diperoleh dari penelitian ini adalah: Hasil pengujian hipotesis menurut kualifikasi menunjukan bahwa kepuasan kerja memiliki pengaruh positif terhadap pemberdayaan. Dengan adanya peningkatan terhadap kepuasan kerja dari dalam diri karyawan maka karyawan pun lebih menginginkan untuk diberikan pemberdayaan. Hal ini ditunjukkan dengan adanya Karyawan merasa senang diberikan kesempatan untuk maju dalam berkarir di perusahaan, sehingga mendorong Karyawan untuk diberdayakan 


\section{Saran}

Penelitian ini diharapkan memberikan masukan bagi manajer Sumber Daya Manusia agar : 1). Menciptakan rasa aman bagi karyawan yang bekerja di perusahaan dengan cara menghindari konflik yang timbul antara pimpinan dan bawahan. 2). Dengan memberikan gaji dan promosi jabatan bagi karyawan agar karyawan memiliki retensi kerja atau karyawan menjadi lebih lama bekerja di dalam perusahaan. 3). Dengan meningkatkan keahlian dan keterampilan dalam bekerja sehingga karyawan menjadi lebih memiliki kemampuan untuk bekerja di dalam perusahaan. 4). Saran-saran yang dapat diberikan untuk penelitian selanjutnya antara lain: a). Penelitian ini tidak hanya menggunakan responden karyawan pada divisi Sumber Daya Manusia tetapi penelitian yang akan datang dapat menggunakan responden karyawan pada divisi Sumber Daya Manusia. b). Penelitian ini hanya meneliti mengenai variabel kepuasan kerja, pengalaman kerja, dan pemberdayan tetapi penelitian yang akan datang dapat meneliti mengenai variabel keterlibatan kerja sesuai dengan rekomendasi dari Gill, Sharma, Mathur, dan Bhutani (2012).

\section{DAFTAR PUSTAKA}

Abdulla, J., Djebarni, R., and Mellahi, K. (2011), "Determinants of job satisfaction in the UAE: A case study of the Dubai police", Journal of Personnel Review, Vol. 40 No.(1), pp. 126-146.

Arneson, H. and Ekberg, K. (2006), "Measuring empowerment in working life: A review", Work, Vol. 26, pp. 37-46.

Bhatti, K. and Shahzad, I. (2008), "Antecedents of compensation and relationship among compensation, motivation, and organization profitability", Business Review, Vol. 56, pp. 788-796.

Cunnien, K., A., Rogers,N, M. and Mortimer, J,T. (2009), "Adolescent work experience and self-efficacy", International Journal of Sociology and Social Policy, Vol. 29, pp. 164175.

Gill, Suraj P. Sharma, Neil Mathur, Smita Bhutani, (2012), "The Effects of Job Satisfaction and Work Experience on Employee-Desire for Empowerment: A Comparative Study in Canada and India", International Journal of Management, Vol.29 No.(1), pp. 190-200.

Gill, A., Fitzgerald, S., Bhutani, S., Mand, H. (2010), "The relationship between transformational leadership and employee desire for empowerment", International Journal of Contemporary Hospitality Management, Vol. 22 No.2, pp.263-73.

Greenhaus, H.J., Tammy, D.A., and Spector, P.E. (2006), "Health consequences of work-family: the dark side of the work-family interface", Research in Occopational Stress and WellBeing, Vol.5, pp. 61-98.

Gunlu, E., Aksarayli, M. and Percin, N.S. (2010), "Job satisfaction and organizational commitment of hotel managers in Turkey", International Journal of Contemporary Hospitality Management, Vol. 22 No. 5, pp.693 - 717 .

Kinicki, A. and Kreitner, R.(2005). Organizational Behavior: Key concepts, Skills \& Best Practices. McGraw-Hill, Irwin.

Kumar, K., Bakhshi, A., and Rani, E. (2009), "Organizational Justice Perceptions as Predictor of Job Satisfaction and Organizational Commitment", IUP Journal of 
Management Research,Vol.8, pp.24-37.

Lim, S. (2008), "Job satisfaction of information technology workers in academic libraries", Library and Information Science, Vol.30, pp. 15-121.

Macky, K. and Boxall, P. (2008), "Highinvolvement work processes, work intensification and employee wellbeing: a study of New Zealand worker experiences", Asia Pacific Journal of Human Resources, Vol. 46 No. (2), pp. 38-55.

Mathieu, J. E., Gilson, L. L., \& Ruddy, T. M. (2006), "Empowerment and team effectiveness: An empirical test of an integrated model", Journal of Applied Psychology, 91: 97-108.

Petrescu, A.I. and Simmons, R. (2008), "Human resource management practices and workers' job satisfaction", International Journal of Manpower, Vol. 29 No. 7, pp.651-667.

Poon, J. M. L. (2004), "Career commitment and career success: moderating role of emotion perception", Career Development International, Vol.9 No.(4), pp. 374-390.

Robbins dan Judge (2008). Perilaku Organisasi, Buku 1, Cet. 12. Jakarta: Salemba Empat .

Robbins, S.P. and Judge, T.A. (2009). Organizational Behavior. Upper Saddle River, NJ: Prentice Hall.
Sarmiento, R., Beale, J., and Graeme Knowles, (2007), "Determinants of performance amongst shop-floor employees: A preliminary investigation", Management Research News, Vol. 30 No. 12, pp.915-927.

Sarwar, A. and Khalid, A. (2011), "Impact of Employee Empowerment on Employee's Job Satisfaction and Commitment with the Organization", Interdiscliplinary Journal of Contemporary Research in Business, 3(2), pp.664-684.

Scroggins, W.A. (2008), "Antecedents and Outcomes of Experienced Meaningful Work:A person", Job Fit Perspective.

Sulis, G. (2009). Wage Returns to Experience and Tenure for Young Men in Italy. Ricerche Economiche.

Van Rooy, D.L., Alonso, A., \& Viswesvaran, C. (2005). Group differences in emotional intelligence scores: Theoretical and practical implications. Personality and Individual Differences, Vol.38, pp. 689-700.

Zimmerman, R. D. and Darnold, T. C. (2009), "The impact of job performance on employee turnover intentions and the voluntary turnover process: A Meta-analysis and path model", Personnel Review, pp. 142-158. 